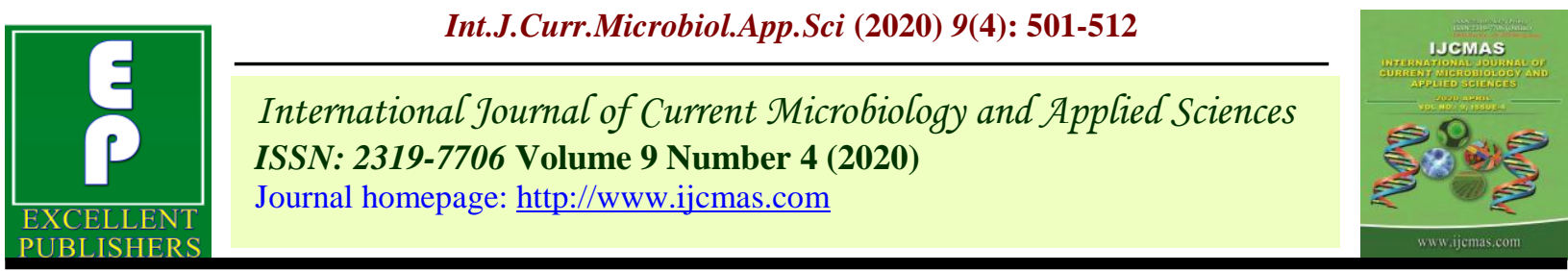

\title{
Effect of Soil and Foliar Application of Zinc on Growth and Yield of Greengram (Vigna radiate $\mathrm{L}$. )
}

\author{
H. V. Vinodkumar, S. Channakeshava*, B. Basavaraja and Ananathakumar \\ College of Agriculture, V.C Farm Mandya, University of Agricultural Sciences, \\ Bengaluru-560065, Karnataka, India \\ *Corresponding author
}

\begin{tabular}{|l|}
\hline K e y w o r d s \\
Zinc sulphate, $\mathrm{Zn}$ \\
EDTA, Foliar spray \\
\hline Article Info \\
\hline $\begin{array}{l}\text { Accepted: } \\
\text { 07 March } 2020 \\
\text { Available Online: } \\
\text { 10 April } 2020\end{array}$ \\
\hline
\end{tabular}

A B S T R A C T

\begin{abstract}
A field experiment was conducted to study the Response of greengram to soil and foliar application of zinc in southern dry zone of Karnataka during early kharif 2018 at Junjanahally, Hassan. Experiments consist of nine treatments replicated thrice with RCBD. Results revealed that significantly higher growth and yield parameters such as plant height $(71.93 \mathrm{~cm})$ number of branches per plant(4.37), number of effective nodules per plant $(28.07)$ dry matter production per plant $(27.07 \mathrm{~g})$, pod length $(13.60 \mathrm{~cm})$ number of pods per plant(24.40), number of seeds per pod (13.40), pod weight per plant $(29.73 \mathrm{~g})$,seed yield $(1022.99 \mathrm{~kg} / \mathrm{ha})$ and haulm yield $(2544.93 \mathrm{~kg} / \mathrm{ha})$ were recorded with T9 (soil application of zinc sulphate @ $10 \mathrm{~kg} / \mathrm{ha}+$ foliar spray of zinc EDTA at 1.0 percent along with NPK and FYM). The available nitrogen, phosphorus and potassium content of soil were non significant however higher nitrogen and potassium recorded $(239.80 \&$ $177.10 \mathrm{~kg} / \mathrm{ha}$ ) in the treatment $\mathrm{T} 1(\mathrm{NPK}+\mathrm{FYM})$ and lower nitrogen and potassium recorded (232.70 \&171.40 kg/ha)in T9 (T3 + FSZn EDTA @ 1.0\%). Higher phosphorus recorded in T9 $(44.70 \mathrm{~kg} / \mathrm{ha})$. As regard to DTPA extractable micronutrients in soil, low iron (7.69 $\mathrm{mg} / \mathrm{kg}$ ), copper $(0.369 \mathrm{ppm})$, manganese $(8.16 \mathrm{ppm})$ and Boron $(0.35 \mathrm{mg} / \mathrm{kg})$ content in soil was recorded in T9 (T3+ FS of Zn EDTA).Application of zinc increased carbonate bound zinc $(3.14 \mathrm{mg} / \mathrm{kg})$, , organic bound zinc $(1.73 \mathrm{mg} / \mathrm{kg})$ and $\mathrm{Fe}$ and $\mathrm{Al}$ oxide bound zinc (2.84 $\mathrm{mg} / \mathrm{kg}$ ) was recorded in T3 (T1+ SA of $\mathrm{ZnSO}_{4} @ 10 \mathrm{~kg} / \mathrm{ha}$ ) over with NPK+ FYM. The higher total zinc was observed in the treatment T9 $(130.42 \mathrm{mg} / \mathrm{kg})$ which received T3+ FS of Zn EDTA@ 1.0 percent followed by treatment T7 $(135.32 \mathrm{mg} / \mathrm{kg}$ ) and lowest Zn content was recorded $(130.42 \mathrm{mg} / \mathrm{kg})$ in the treatment $\mathrm{T} 1(\mathrm{NPK}+\mathrm{FYM})$.
\end{abstract}

\section{Introduction}

Pulses play a pivotal role in nutritional security. considering this Food and Agriculture Organization (FAO) has marked year 2016 as international year of pulses to show-cause the importance of pulses in human and animal nutrition. Pulses are importance sources of protein, vitamin and minerals. Important pulses which grown in India are greengram, chickpea pigeon pea horse gram, cowpea and rice bean. It is asserted that in India pulse are cultivated on an area of 29.36 mha with a production and productivity of $24.51 \mathrm{mt}$ and $835 \mathrm{~kg}$ per hectare (Anon., 2018). Low productivity of of 
these pulses ascribed to the conditions under which these are grown. In general pulses grown in rainfed area in marginal soils under residual moisture conditions and most importantly without or merger fertilizer input.

Green gram known as Mung or Golden gram is native to Indian continent. Apart from India it is also grown in China, Thailand, Indonesia, Burma, Bangladesh, Laos and Cambodia and also in hot and dry regions of southern Europe and southern united states. The favourable conditions for its better growth and development are warm humid climate with an optimum temperature range of $25^{\circ}$ to $35^{0} \mathrm{C}$ with moderate rains of $80-100 \mathrm{~cm}$. Normally it is sown during April to June as high temperature and low humidity keeps insects and diseases infestations at below threshold level(Anon,2017a). In India it is grown on an area of 43.05 lakh hectare with annual production of 20.70 lakh tonne and productivity of 481 kgper hectare (Anno., 2017b). Greengram contains 25 percent protein, 1.3 percent fat and 57 percent carbohydrate. Green gram is also rich source of calcium (68 mg/100gseed), phosphorus $(300 \mathrm{~g} / 100 \mathrm{~g}$ seed) and Iron $(7 \mathrm{mg} / 100 \mathrm{gseed})$. It is one of the main source of protein and certain essential amino acids like tryptophan and lysine in vegetarian diets. It also a rich source of energy and provides 334 kilocalories of energy (Srivastava and Ali, 2004). Wide spread deficiency of micronutrient has become major constraint for achieving higher genetic potential yield of greengram along with quality of crop. Among the micronutrients the deficiency of Zinc and boron has become wide spread in recent years all over the country. In India next to Nitrogen, phosphorus, potassium and sulphur $5^{\text {th }}$ important yield limiting nutrient is zinc which accounts for 48 percent of Indian soils. Hence, an investigation entitled "Response of greengram (Vigna radiata L.) to soil and foliar application of zinc in Southern Dry Zone of Karnataka" was carried out

\section{Materials and Methods}

A field experiment was conducted during early Kharif 2018 to study the "Response of greengram (Vigna radiata L.) to soil and foliar application of zinc in Southern Dry Zone of Karnataka" at farmers field, Junjanahalli, Hassan, Karnataka. The soil was sandy loam in texture with 78.10, 4.90 and 17.00 per cent sand, silt and clay, respectively. The soil was slightly alkaline inpH (8.0) reaction and normal in soluble salts $\left(0.24 \mathrm{dS} \mathrm{m}^{-1}\right)$. The soil was low in organic carbon (4.8 $\mathrm{g} \mathrm{kg}^{-1}$ ) content and medium in available nitrogen (298 kg ha-1), available $\mathrm{P}_{2} \mathrm{O}_{5}\left(38.5 \mathrm{~kg} \mathrm{ha}^{-1}\right)$, available $\mathrm{K}_{2} \mathrm{O}$ (189 $\mathrm{kg} \mathrm{ha}^{-1}$ ) and low in sulphur $(9.1 \mathrm{mg}$ $\left.\mathrm{kg}^{-1}\right)$. Exchangeable calcium and magnesium content of soil was 3.6 and $1.7 \mathrm{cmol} \mathrm{kg}^{-1}$, respectively. The soil selected was deficient in zinc with zinc content of $0.52 \mathrm{mg} \mathrm{kg}^{-1}$ and the DTPA extractable micronutrient content viz., iron, copper, manganese and hot water soluble boron were $8.65,0.42,8.93$ and 0.38 $\mathrm{mg} \mathrm{kg}$, respectively. Experiment was laid out during early Kharif 2018 in Randomized Complete Block Design. There are nine treatments replicated thrice. The size of each plot was $5.1 \mathrm{~m} \mathrm{x} 2 \mathrm{~m}$ (gross). Treatments were distributed randomly in the plots within the blocks (Table 1).

The treatment details of the research are as follows:

T1: NPK + FYM T2: $\mathrm{T}_{1}+\mathrm{SA}$ of $\mathrm{ZnSO}_{4} \cdot 7 \mathrm{H}_{2} \mathrm{O}$ @ $5 \mathrm{~kg} \mathrm{ha}^{-1} \mathrm{~T} 3: \mathrm{T}_{1}+\mathrm{SA}$ of $\mathrm{ZnSO}_{4} .7 \mathrm{H}_{2} \mathrm{O} @ 10$ $\mathrm{kg} \mathrm{ha}^{-1}$

T4: $\mathrm{T}_{1}+$ FS of Zn EDTA @ $0.50 \%$ T5: $\mathrm{T}_{1}+$ FS of Zn EDTA@1.00\%

T6: $\mathrm{T}_{2}+$ FS of Zn EDTA @ $0.50 \%$ T7: $\mathrm{T}_{3}+$ FS of Zn EDTA@ $0.50 \%$

T8: $\mathrm{T}_{2}+$ FSof Zn EDTA @ $1.00 \%$ T9: $\mathrm{T}_{3}+$ FS of Zn EDTA @ $1.00 \%$

NPK: 12.5:25:25 N: $\mathrm{P}_{2} \mathrm{O}_{5}: \mathrm{K}_{2} \mathrm{Okg}$ ha $^{-1}$ FYM: Farm yard manure. SA: Soil application. FS: Foliar spray at 35 DAS. 


\section{Zn EDTA}

Zinc Ethylene diamine tetra acetic acid. Greengram variety BGS-9 was grown as a test crop.

\section{Fertilizer application}

The calculated quantity of urea, diammonium phosphate (DAP) and murate of potash (MOP) i.e. 5.89: 54.34: $41.66 \mathrm{~kg} \mathrm{ha}{ }^{-1}$, respectively was used to supply $\mathrm{N}, \mathrm{P}, \mathrm{K}$ respectively as per the treatments. The fertilizers were applied at the time of sowing as basal.

All the fertilizers were applied in line opened $4 \mathrm{~cm}$ away from the seed row and mixed well with soil. Soil application of zinc was took at the time of sowing and foliar spray of zinc EDTA at 35 DAS. Greengram seeds were inoculated with rhizobium inoculum before sowing and sown with spacing of $30 \mathrm{~cm} \mathrm{X} 10$ $\mathrm{cm}$.

Biometric observations on growth parameters like plant height, number of leaves per plant, leaf area, dry matter production, Number of nodules and effective nodules. Yield attributing parameters like number of pods per plant, number of seeds per plant, pod length, pod weight and test weight were recorded. Soil and plant samples were analysed for major (NPK) and micronutrient $(\mathrm{Cu} \mathrm{Zn} \mathrm{Fe} \mathrm{Mn})$ using standard procedure prescribed by Jackson (1973) and Lindsay and Norwel (1978).

Estimation of total zinc in soils is described by Sridhar and Jackson (1974). The concentration of zinc in the above solutions was determined by atomic absorption spectrophotometer under suitable measuring conditions (Page et al., 1982). Estimation of Fractions of zinc in soils defined as given below (Ma and Uren, 1995).

\section{Results and Discussion}

Results of experiment revealed that the growth parameters like plant height (70.27 $\mathrm{cm})$ and drymatter production $(27.07 \mathrm{~g})$ was higher in treatments receiving soil application of zinc sulphate @ $10 \mathrm{~kg}$ per hectare and foliar application of $1 \% \mathrm{Zn}$ EDTA along with NPK+ FYM which was on par with T3(NPK+FYM+SA of $\mathrm{Zn}$ and FS of ZnEDTA0.5\%). Lower plant height $(60.73 \mathrm{~cm})$ and dry matter production was recorded in T1(NPK+FYM applied).

The higher plant height and dry matter production was attributed to sufficient supply of zinc through foliar spray and soil application which influenced on growth and development of plant. Similar results were also recorded by Akay (2011).

Significantly higher pod length $(13.60 \mathrm{~cm})$, number of pods plant ${ }^{-1}$ (24.40), number of seeds $\operatorname{pod}^{-1}(13.40)$, pod weight per plant ${ }^{1}(29.73 \mathrm{~g})$ and test weight $(5.58 \mathrm{~g})$ were obtained in treatment $\mathrm{T}_{9}$ with soil application of zinc sulphate at $10 \mathrm{~kg} \mathrm{ha}^{-1}+$ foliar spray of zinc EDTA at $1.00 \%$ along with NPK and FYM. Lower pod length $(11.53 \mathrm{~cm})$, number of pods per plant, pod weight and test weight recorded in T1 (NPK + FYM).

The positive effect of zinc on growth character might be due to its direct influence on synthesis of tryptophan, a precursor for production of growth hormone i.e. auxin. Auxin has key role in cell elongation process which in turn helps in plant growth and development (Krishna, 1995) (Table 2 and 3).

\section{Seed yield $\left(\mathrm{kg} \mathrm{ha}^{-1}\right)$}

Significantly higher seed yield was obtained with the application of $\mathrm{T}_{9}\left(\mathrm{~T}_{3}+\mathrm{FS}\right.$ of $\mathrm{Zn}$ EDTA@ $1.00 \%)\left(1022.19 \mathrm{~kg} \mathrm{ha}^{-1}\right)$ which was significantly superior over the treatments 
$\mathrm{T}_{1}\left(805.51 \mathrm{~kg} \mathrm{ha}^{-1}\right), \mathrm{T}_{2}\left(938.14 \mathrm{~kg} \mathrm{ha}^{-1}\right), \mathrm{T}_{4}$ $\left(879.51 \mathrm{~kg} \mathrm{ha}^{-1}\right), \mathrm{T}_{5}\left(905.84 \mathrm{~kg} \mathrm{ha}^{-1}\right)$ and $\mathrm{T}_{6}$ $\left(943.89 \mathrm{~kg} \mathrm{ha}^{-1}\right)$ and it was on par with $\mathrm{T}_{7}$ $\left(982.65 \mathrm{~kg} \mathrm{ha}^{-1}\right), \mathrm{T}_{8}\left(968.50 \mathrm{~kg} \mathrm{ha}^{-1}\right)$, and $\mathrm{T}_{3}$ $\left(973.00 \mathrm{~kg} \mathrm{ha}^{-1}\right)$.

\section{Haulm yield $\left(\mathrm{kg} \mathrm{ha}^{-1}\right)$}

The effect of soil and foliar application of zinc on haulm yield is presented in Table 4 . Significantly higher haulm yield was obtained with the application of $\mathrm{T}_{9}\left(\mathrm{~T}_{3}+\mathrm{FS}\right.$ of $\mathrm{Zn}$ EDTA@ @ $1.00 \%)\left(2544.93 \mathrm{~kg} \mathrm{ha}^{-1}\right)$ which was on par with $\mathrm{T}_{3}\left(2453.43 \mathrm{~kg} \mathrm{ha}^{-1}\right), \mathrm{T}_{6}$ (2417.00 kg ha $\left.{ }^{-1}\right), \mathrm{T}_{7}\left(2458.57 \mathrm{~kg} \mathrm{ha}^{-1}\right)$ and $\mathrm{T}_{8}$ $\left(2442.39 \mathrm{~kg} \mathrm{ha}^{-1}\right)$ and was significantly superior over the treatments $T_{1}(2217.80 \mathrm{~kg}$ $\left.\mathrm{ha}^{-1}\right), \mathrm{T}_{2}\left(2402.26 \mathrm{~kg} \mathrm{ha}^{-1}\right), \mathrm{T}_{4}(2387.88 \mathrm{~kg}$ $\left.\mathrm{ha}^{-1}\right)$ and $\mathrm{T}_{5}\left(2390.27 \mathrm{~kg} \mathrm{ha}^{-1}\right)$.

The adequate availability of zinc in soil results in growth parameters, photosynthesis efficiency, assimilation and production (Ali, 2004) and in turn to achieve higher yield and yield attributes in basal or combined application treatments i.e. $\mathrm{T}_{9}\left(\mathrm{~T}_{3}+\mathrm{FS}\right.$ of $\mathrm{Zn}$ EDTA@ $1.00 \%), \mathrm{T}_{7}\left(\mathrm{~T}_{3}+\mathrm{FS}\right.$ of Zn EDTA @ $0.50 \%), \mathrm{T}_{8}\left(\mathrm{~T}_{2}+\right.$ FS of Zn EDTA @ 1.00 $\%), \mathrm{T}_{6}\left(\mathrm{~T}_{2}+\mathrm{FS}\right.$ of Zn EDTA @ $\left.0.50 \%\right), \mathrm{T}_{3}$ $\left(\mathrm{T}_{1}+\mathrm{SA}\right.$ of $\left.\mathrm{ZnSO}_{4} 7 \mathrm{H} 2 \mathrm{O} @ 10 \mathrm{~kg} \mathrm{ha}^{-1}\right)$ and $\mathrm{T}_{2}\left(\mathrm{~T}_{1}+\mathrm{SA}\right.$ of $\left.\mathrm{ZnSO}_{4} 7 \mathrm{H} 2 \mathrm{O} @ 5 \mathrm{~kg} \mathrm{ha}^{-1}\right)$. The findings are also in agreement with the verdicts of Yashona et al., (2018).

The available Nitrogen, phosphorous and potassium content of the soil after harvest was non-significant. However the lower Nitrogen and potassium content were found in treatment $\mathrm{T}_{9}\left(\mathrm{~T}_{3}+\right.$ FS of Zn EDTA @ $\left.1.00 \%\right)$ which were $232.70 \mathrm{~kg} \mathrm{ha}^{-1}$ and $171.40 \mathrm{~kg} \mathrm{ha}^{-1}$ respectively and higher $\mathrm{N}$ and $\mathrm{K}_{2} \mathrm{O}$ content were found in treatment $\mathrm{T}_{1}(\mathrm{NPK}+\mathrm{FYM})$ which were $239.80 \mathrm{~kg} \mathrm{ha}^{-1}$ and $177.10 \mathrm{~kg} \mathrm{ha}^{-1}$. Higher $\mathrm{P}_{2} \mathrm{O}_{5}$ content was found in treatment $\mathrm{T}_{9}$ $\left(44.70 \mathrm{~kg} \mathrm{ha}^{-1}\right)$ and lowest was recorded in treatment $\mathrm{T}_{1}\left(41.60 \mathrm{~kg} \mathrm{ha}^{-1}\right)$ (Table 5).
The data on DTPA extractable Fe, Mn, Zn, $\mathrm{Cu}$ and hot water soluble B status $\left(\mathrm{g} \mathrm{ha}^{-1}\right)$ of soil at harvest of crop as influenced by soil and foliar application of zinc are presented as below.

\section{Iron}

The iron content did not vary significantly among the treatments. However, higher iron content was observed in the treatment $\mathrm{T}_{1}$ (7.90 mg kg-1) which received NPK along with FYM, followed by $\mathrm{T}_{4}\left(7.87 \mathrm{mg} \mathrm{kg}^{-1}\right)$. The lowest was in $\mathrm{T}_{9}\left(\mathrm{~T}_{3}+\right.$ FS of Zn EDTA @ $1.00 \%)\left(7.69 \mathrm{mg} \mathrm{kg}^{-1}\right)$.

\section{Manganese}

The manganese content did not vary significantly among the treatments. However, higher manganese content was observed in the treatment $\mathrm{T}_{1}\left(8.27 \mathrm{mg} \mathrm{kg}{ }^{-1}\right)$ which received NPK along with FYM, followed by $\mathrm{T}_{5}$ and $\mathrm{T}_{7}\left(8.25 \mathrm{mg} \mathrm{kg}^{-1}\right)$. The lowest was in $\mathrm{T}_{9}\left(\mathrm{~T}_{3}+\mathrm{FS}\right.$ of Zn EDTA @ $\left.1.00 \%\right)(8.16 \mathrm{mg}$ $\left.\mathrm{kg}^{-1}\right)$.

\section{Zinc}

The data in Table 6 indicated that DTPA extractable $\mathrm{Zn}$ content in soil differed significantly due to treatments. Higher zinc content in soil was recorded in $\mathrm{T}_{9}(0.90 \mathrm{mg}$ $\mathrm{kg}^{-1}$ ) which receivedT $\mathrm{T}_{3}+\mathrm{FS}$ of Zn EDTA@ 1.00 per cent which was on par with $\mathrm{T}_{7}$ and $\mathrm{T}_{3}$ which were $0.88 \mathrm{mg} \mathrm{kg}^{-1}$ and $0.87 \mathrm{mg} \mathrm{kg}^{-}$ ${ }^{1}$ respectively and was significantly higher than Treatment $\mathrm{T}_{1}$ i.e, NPK + FYM $(0.46 \mathrm{mg}$ $\left.\mathrm{kg}^{-1}\right)$ and rest of the treatments $\left(\mathrm{T}_{2}, \mathrm{~T}_{4}, \mathrm{~T}_{5}, \mathrm{~T}_{6}\right.$ and $\mathrm{T}_{8}$ ).

The data on DTPA extractable Fe, Mn, Zn, $\mathrm{Cu}$ and hot water soluble $\mathrm{B}$ status $\left(\mathrm{g} \mathrm{ha}^{-1}\right)$ of soil at harvest of crop as influenced by soil and foliar application of zinc are presented in the Table 6 and Table 8. 


\section{Iron}

The iron content did not vary significantly among the treatments. However, higher iron content was observed in the treatment $\mathrm{T}_{1}$ (7.90 $\mathrm{mg} \mathrm{kg}^{-1}$ ) which received NPK along with FYM, followed by $\mathrm{T}_{4}\left(7.87 \mathrm{mg} \mathrm{kg}^{-1}\right)$. The lowest was in $\mathrm{T}_{9}\left(\mathrm{~T}_{3}+\mathrm{FS}\right.$ of Zn EDTA @ $1.00 \%)\left(7.69 \mathrm{mg} \mathrm{kg}^{-1}\right)$.

\section{Manganese}

The manganese content did not vary significantly among the treatments. However, higher manganese content was observed in the treatment $\mathrm{T}_{1}\left(8.27 \mathrm{mg} \mathrm{kg} \mathrm{kg}^{-1}\right)$ which received NPK along with FYM, followed by $\mathrm{T}_{5}$ and $\mathrm{T}_{7}\left(8.25 \mathrm{mg} \mathrm{kg}^{-1}\right)$. The lowest was in $\mathrm{T}_{9}\left(\mathrm{~T}_{3}+\mathrm{FS}\right.$ of Zn EDTA @ $\left.1.00 \%\right)(8.16 \mathrm{mg}$ $\left.\mathrm{kg}^{-1}\right)$.

\section{Zinc}

The DTPA extractable $\mathrm{Zn}$ content in soil differed significantly due to treatments. Higher zinc content in soil was recorded in $\mathrm{T}_{9}$ $\left(0.90 \mathrm{mg} \mathrm{kg}^{-1}\right)$ which received $\mathrm{T}_{3}+\mathrm{FS}$ of $\mathrm{Zn}$
EDTA@ 1.00 per cent which was on par with $\mathrm{T}_{7}$ and $\mathrm{T}_{3}$ which were $0.88 \mathrm{mg} \mathrm{kg}^{-1}$ and 0.87 $\mathrm{mg} \mathrm{kg} \mathrm{kg}^{-1}$ respectively and was significantly higher than Treatment $\mathrm{T}_{1}$ i.e, NPK + FYM $\left(0.46 \mathrm{mg} \mathrm{kg}^{-1}\right)$ and rest of the treatments $\left(\mathrm{T}_{2}\right.$, $\mathrm{T}_{4}, \mathrm{~T}_{5}, \mathrm{~T}_{6}$ and $\mathrm{T}_{8}$ ).

Significantly higher zinc content in soil was recorded in $\mathrm{T}_{9}\left(\mathrm{~T}_{3}+\mathrm{FS}\right.$ of Zn EDTA @ 1.00 $\%)$. The results are in line with the verdicts of Sharma et al., (2016). The increase in zinc content might be due to the considerable exchange of Zinc on the clay complexes with other cations on its addition. The results are in accordance with the findings of Kulandaivel et al., (2004).

\section{Copper}

The treatments had non-significant effect on copper status in soil. However, higher copper content was recorded in $\mathrm{T}_{1}(\mathrm{NPK}+\mathrm{FYM})$ with $0.392 \mathrm{mg} \mathrm{kg}^{-1}$ followed by treatment $\mathrm{T}_{4}$ (0.389 $\mathrm{mg} \mathrm{kg}^{-1}$ ) and lowest copper content was observed in treatment $\mathrm{T}_{9}\left(\mathrm{~T}_{3}+\mathrm{FS}\right.$ of $\mathrm{Zn}$ EDTA@ @ $1.00 \%$ ) which was $0.369 \mathrm{mg} \mathrm{kg}^{-1}$ (Table 7).

Table.1 Fractions of soil at the experimental site

\begin{tabular}{|l|l|l|}
\hline Sl. No & Fraction & Value $\left(\mathbf{m g ~ k g}^{-\mathbf{1}}\right)$ \\
\hline $\mathbf{1 .}$ & Water soluble zinc & 0.37 \\
\hline 2. & Sorbed zinc & 2.10 \\
\hline 3. & Easily reducible manganese bound zinc & 3.71 \\
\hline 4. & Carbonate bound zinc & 2.73 \\
\hline 5. & Organic bound zinc & 1.04 \\
\hline 6. & Fe \& Al oxides bound zinc & 2.44 \\
\hline 7. & Residual zinc & 122.19 \\
\hline 8. & Total zinc & 134.58 \\
\hline
\end{tabular}


Table.2 Effect of soil and foliar application of zinc on growth parameters of greengram

\begin{tabular}{|c|c|c|c|}
\hline \multirow[t]{2}{*}{ Treatments } & \multicolumn{3}{|c|}{ Growth Parameters } \\
\hline & $\begin{array}{l}\text { Plant height } \\
(\mathrm{cm})\end{array}$ & $\begin{array}{c}\text { Drymatter } \\
\text { production (g) }\end{array}$ & $\begin{array}{c}\text { Number of } \\
\text { branches/plant }\end{array}$ \\
\hline$T_{1}:$ NPK + FYM & 60.73 & 20.15 & 3.47 \\
\hline $\begin{array}{l}\mathrm{T}_{2}: \mathrm{T}_{1}+\mathrm{SA} \text { of } \\
\mathrm{ZnSO}_{4} 7 \mathrm{H}_{2} \mathrm{O} @ 5 \mathrm{~kg} \mathrm{ha}^{-1}\end{array}$ & 65.63 & 23.08 & 3.73 \\
\hline $\begin{array}{l}T_{3}: T_{1}+S A \text { of } \\
\mathrm{ZnSO}_{4} 7 \mathrm{H}_{2} \mathrm{O} @ 10 \mathrm{~kg} \mathrm{ha}^{-1}\end{array}$ & 68.93 & 26.02 & 4.20 \\
\hline $\begin{array}{l}T_{4}: T_{1}+\text { FS of Zn EDTA } \\
\text { @ } 0.50 \%\end{array}$ & 63.17 & 21.61 & 3.53 \\
\hline $\begin{array}{l}T_{5}: T_{1}+F S \text { of } \mathrm{Zn} \mathrm{EDTA} \\
\text { @ } 1.00 \%\end{array}$ & 64.40 & 22.00 & 3.60 \\
\hline $\begin{array}{l}T_{6}: T_{2}+F S \text { of } \mathrm{Zn} \mathrm{EDTA} \\
\text { @ } 0.50 \%\end{array}$ & 66.43 & 24.10 & 3.83 \\
\hline $\begin{array}{l}T_{7}: T_{3}+\text { FS of } \mathbf{Z n} \text { EDTA } \\
@ 0.50 \%\end{array}$ & 70.27 & 26.44 & 4.30 \\
\hline $\begin{array}{l}T_{8}: T_{2}+F S \text { of } \mathrm{Zn} \text { EDTA } \\
@ 1.00 \%\end{array}$ & 66.67 & 25.23 & 3.90 \\
\hline $\begin{array}{l}T_{9}: T_{3}+\text { FSof Zn EDTA @ } \\
1.00 \%\end{array}$ & 71.93 & 27.07 & 4.37 \\
\hline S.Em \pm & 1.52 & 0.98 & 0.13 \\
\hline $\mathrm{CD}(\mathrm{P}=0.05)$ & 4.55 & 2.93 & 0.40 \\
\hline
\end{tabular}

Table.3 Effect of soil and foliar application of zinc on yield and yield parameters of greengram

\begin{tabular}{|c|c|c|c|c|c|}
\hline Treatments & $\begin{array}{l}\text { Pod length } \\
\text { (cm) }\end{array}$ & $\begin{array}{l}\text { No. of pods } \\
\text { plant }^{-1}\end{array}$ & $\begin{array}{l}\text { No. of seeds } \\
\text { pod }^{-1}\end{array}$ & $\begin{array}{c}\text { Pod } \\
\text { weight(g) }\end{array}$ & $\begin{array}{l}\text { Test weight } \\
\text { (g) }\end{array}$ \\
\hline$T_{1}: N P K+F Y M$ & 11.53 & 19.27 & 11.80 & 23.33 & 4.89 \\
\hline $\begin{array}{l}\mathrm{T}_{2}: \mathrm{T}_{1}+\mathrm{SA} \text { of } \mathrm{ZnSO}_{4} 7 \mathrm{H}_{2} \mathrm{O} @ 5 \mathrm{~kg} \\
\mathrm{ha}^{-1}\end{array}$ & 12.80 & 22.13 & 12.80 & 25.68 & 5.19 \\
\hline $\begin{array}{l}\mathrm{T}_{3}: \mathrm{T}_{1}+\mathrm{SA} \text { of } \mathrm{ZnSO}_{4} 7 \mathrm{H}_{2} \mathrm{O} @ 10 \\
\mathrm{~kg} \mathrm{ha}^{-1}\end{array}$ & 13.17 & 23.40 & 13.13 & 27.89 & 5.63 \\
\hline$T_{4}: T_{1}+$ FS of Zn EDTA @ $0.50 \%$ & 12.43 & 19.73 & 12.13 & 24.92 & 5.12 \\
\hline$T_{5}: T_{1}+$ FS of Zn EDTA @ $1.00 \%$ & 12.60 & 20.67 & 12.60 & 25.07 & 5.16 \\
\hline$T_{6}: T_{2}+$ FS of Zn EDTA @ $0.50 \%$ & 13.00 & 22.93 & 12.87 & 25.94 & 5.33 \\
\hline$T_{7}: T_{3}+$ FS of Zn EDTA @ $0.50 \%$ & 13.30 & 24.07 & 13.33 & 28.85 & 5.58 \\
\hline$T_{8}: T_{2}+$ FS of Zn EDTA @ $1.00 \%$ & 13.13 & 23.07 & 12.93 & 26.89 & 5.39 \\
\hline$T_{9}: T_{3}+$ FSof Zn EDTA @ $1.00 \%$ & 13.60 & 24.40 & 13.40 & 29.73 & 5.58 \\
\hline S.Em \pm & 0.30 & 0.62 & 0.27 & 0.76 & 0.15 \\
\hline $\mathrm{CD}(\mathrm{P}=\mathbf{0 . 0 5})$ & 0.91 & 1.86 & 0.80 & 2.27 & NS \\
\hline
\end{tabular}


Table.4 Effect of soil and foliar application of zinc on seed, haulm yield and harvest Index of greengram

\begin{tabular}{|c|c|c|c|}
\hline Treatments & Seed Yield (kg/ha) & $\begin{array}{c}\text { Haulm yield } \\
\text { (kg/ha) }\end{array}$ & Harvest Index (\%) \\
\hline$T_{1}: N P K+F Y M$ & 805.51 & 2217.80 & 0.267 \\
\hline $\mathrm{T}_{2}: \mathrm{T}_{1}+\mathrm{SA}$ of $\mathrm{ZnSO}_{4} 7 \mathrm{H}_{2} \mathrm{O} @ 5 \mathrm{~kg} \mathrm{ha}^{-1}$ & 938.14 & 2402.26 & 0.281 \\
\hline $\mathrm{T}_{3}: \mathrm{T}_{1}+\mathrm{SA}$ of $\mathrm{ZnSO}_{4} 7 \mathrm{H}_{2} \mathrm{O} @ 10 \mathrm{~kg} \mathrm{ha}^{-1}$ & 973.00 & 2453.43 & 0.284 \\
\hline$T_{4}: T_{1}+$ FS of Zn EDTA @ $0.50 \%$ & 879.51 & 2387.88 & 0.269 \\
\hline$T_{5}: T_{1}+F S$ of Zn EDTA @ $1.00 \%$ & 905.84 & 2390.27 & 0.275 \\
\hline$T_{6}: T_{2}+$ FS of Zn EDTA @ $0.50 \%$ & 943.89 & 2417.00 & 0.281 \\
\hline$T_{7}: T_{3}+$ FS of Zn EDTA @ $0.50 \%$ & 982.65 & 2458.57 & 0.285 \\
\hline$T_{8}: T_{2}+$ FS of Zn EDTA @ $1.00 \%$ & 968.50 & 2442.39 & 0.284 \\
\hline$T_{9}: T_{3}+$ FSof Zn EDTA @ $1.00 \%$ & 1022.19 & 2544.93 & 0.287 \\
\hline S.Em \pm & 24.62 & 43.06 & 0.006 \\
\hline $\mathrm{CD}(\mathbf{P}=0.05)$ & 73.81 & 129.09 & NS \\
\hline
\end{tabular}

Table.5 Available $\mathrm{N}, \mathrm{P}_{2} \mathrm{O}_{5}$ and $\mathrm{K}_{2} \mathrm{O}$ content of soil after harvest of greengram as influenced by soil and foliar application of zinc

\begin{tabular}{|c|c|c|c|}
\hline Treatment & $\begin{array}{c}\mathrm{N} \\
\left(\mathrm{kg} \mathrm{ha}^{-1}\right)\end{array}$ & $\begin{array}{c}\mathrm{P}_{2} \mathrm{O}_{5} \\
\left(\mathrm{~kg} \mathrm{ha}^{-1}\right)\end{array}$ & $\begin{array}{c}\mathrm{K}_{2} \mathrm{O} \\
\left(\mathrm{kg} \mathrm{ha}^{-1}\right)\end{array}$ \\
\hline $\mathrm{T}_{1}: \mathbf{N P K}+\mathrm{FYM}$ & 239.80 & 41.60 & 177.10 \\
\hline $\mathrm{T}_{2}: \mathrm{T}_{1}+\mathrm{SA}$ of $\mathrm{ZnSO}_{4} 7 \mathrm{H}_{2} \mathrm{O} @ 5 \mathrm{~kg} \mathrm{ha}^{-1}$ & 236.62 & 42.10 & 174.23 \\
\hline $\mathrm{T}_{3}: \mathrm{T}_{1}+\mathrm{SA}$ of $\mathrm{ZnSO}_{4} 7 \mathrm{H}_{2} \mathrm{O} @ 10 \mathrm{~kg} \mathrm{ha}^{-1}$ & 234.60 & 43.80 & 171.60 \\
\hline $\mathrm{T}_{4}: \mathrm{T}_{1}+\mathrm{FS}$ of Zn EDTA @ $0.50 \%$ & 239.64 & 42.96 & 176.14 \\
\hline$T_{5}: T_{1}+$ FS of Zn EDTA @ $1.00 \%$ & 237.50 & 43.80 & 175.55 \\
\hline$T_{6}: T_{2}+$ FS of Zn EDTA @ $0.50 \%$ & 237.20 & 44.30 & 173.30 \\
\hline$T_{7}: T_{3}+$ FS of Zn EDTA @ $0.50 \%$ & 234.80 & 42.80 & 172.80 \\
\hline $\mathrm{T}_{8}: \mathrm{T}_{2}+\mathrm{FS}$ of Zn EDTA @ $1.00 \%$ & 238.90 & 43.90 & 174.90 \\
\hline$T_{9}: T_{3}+$ FS of Zn EDTA @ $1.00 \%$ & 232.70 & 44.70 & 171.40 \\
\hline S.Em \pm & 6.27 & 1.61 & 5.21 \\
\hline $\mathrm{CD}(\mathrm{P}=0.05)$ & NS & NS & NS \\
\hline
\end{tabular}

SA: Soil application

FS: Foliar spray at 35 DAS 
Table.6 DTPA extractable iron, manganese and zinc content of soil after harvest of greengram as influenced by soil and foliar application of zinc

\begin{tabular}{|c|c|c|c|}
\hline Treatment & $\mathrm{Fe}\left(\mathrm{mg} \mathrm{kg}^{-1}\right)$ & $\operatorname{Mn}\left(\mathrm{mg} \mathrm{kg}^{-1}\right)$ & $\mathrm{Zn}\left(\mathrm{mg} \mathrm{kg}^{-1}\right)$ \\
\hline $\mathrm{T}_{1}: \mathrm{NPK}+\mathrm{FYM}$ & 7.90 & 8.27 & 0.46 \\
\hline $\mathrm{T}_{2}: \mathrm{T}_{1}+\mathrm{SA}$ of $\mathrm{ZnSO}_{4} 7 \mathrm{H}_{2} \mathrm{O} @ 5 \mathrm{~kg} \mathrm{ha}^{-1}$ & 7.79 & 8.21 & 0.79 \\
\hline $\mathrm{T}_{3}: \mathrm{T}_{1}+\mathrm{SA}$ of $\mathrm{ZnSO}_{4} 7 \mathrm{H}_{2} \mathrm{O} @ 10 \mathrm{~kg} \mathrm{ha}^{-1}$ & 7.76 & 8.19 & 0.87 \\
\hline$T_{4}: T_{1}+$ FS of Zn EDTA @ $0.50 \%$ & 7.87 & 8.24 & 0.48 \\
\hline$T_{5}: T_{1}+$ FS of Zn EDTA @ $1.00 \%$ & 7.81 & 8.25 & 0.50 \\
\hline$T_{6}: T_{2}+$ FS of Zn EDTA @ $0.50 \%$ & 7.79 & 8.22 & 0.81 \\
\hline$T_{7}: T_{3}+$ FS of Zn EDTA @ $0.50 \%$ & 7.72 & 8.25 & 0.88 \\
\hline$T_{8}: T_{2}+$ FS of Zn EDTA @ $1.00 \%$ & 7.70 & 8.21 & 0.82 \\
\hline$T_{9}: T_{3}+$ FS of Zn EDTA @ $1.00 \%$ & 7.69 & 8.16 & 0.90 \\
\hline S.Em \pm & 0.23 & 0.25 & 0.02 \\
\hline $\mathrm{CD}(\mathrm{P}=0.05)$ & NS & NS & 0.07 \\
\hline
\end{tabular}

NOTE:

SA: Soil application

FS: Foliar spray at 35 DAS

Table.7 DTPA extractable copper and hot water soluble boron content of soil

\begin{tabular}{|c|c|c|}
\hline Treatment & $\mathrm{Cu}\left(\mathrm{mg} \mathrm{kg}^{-1}\right)$ & B $\left(\mathrm{mg} \mathrm{kg}^{-1}\right)$ \\
\hline $\mathrm{T}_{1}: \mathrm{NPK}+\mathrm{FYM}$ & 0.392 & 0.35 \\
\hline $\mathrm{T}_{2}: \mathrm{T}_{1}+\mathrm{SA}$ of $\mathrm{ZnSO}_{4} 7 \mathrm{H}_{2} \mathrm{O} @ 5 \mathrm{~kg} \mathrm{ha}^{-1}$ & 0.386 & 0.34 \\
\hline $\mathrm{T}_{3}: \mathrm{T}_{1}+\mathrm{SA}$ of $\mathrm{ZnSO}_{4} 7 \mathrm{H}_{2} \mathrm{O} @ 10 \mathrm{~kg} \mathrm{ha}^{-1}$ & 0.381 & 0.32 \\
\hline$T_{4}: T_{1}+$ FS of Zn EDTA @ $0.50 \%$ & 0.389 & 0.33 \\
\hline$T_{5}: T_{1}+$ FS of Zn EDTA @ $1.00 \%$ & 0.381 & 0.33 \\
\hline$T_{6}: T_{2}+$ FS of Zn EDTA @ $0.50 \%$ & 0.383 & 0.33 \\
\hline$T_{7}: T_{3}+$ FS of Zn EDTA @ $0.50 \%$ & 0.378 & 0.32 \\
\hline$T_{8}: T_{2}+$ FS of Zn EDTA @ $1.00 \%$ & 0.373 & 0.33 \\
\hline$T_{9}: T_{3}+$ FS of Zn EDTA @ $1.00 \%$ & 0.369 & 0.31 \\
\hline S.Em \pm & 0.012 & 0.01 \\
\hline $\mathrm{CD}(\mathrm{P}=\mathbf{0 . 0 5})$ & NS & NS \\
\hline
\end{tabular}


Table.8 Distribution of zinc fractions $\left(\mathrm{mg} \mathrm{kg}^{-1}\right)$ in soil at harvest of greengram as influenced by soil and foliar application of zinc

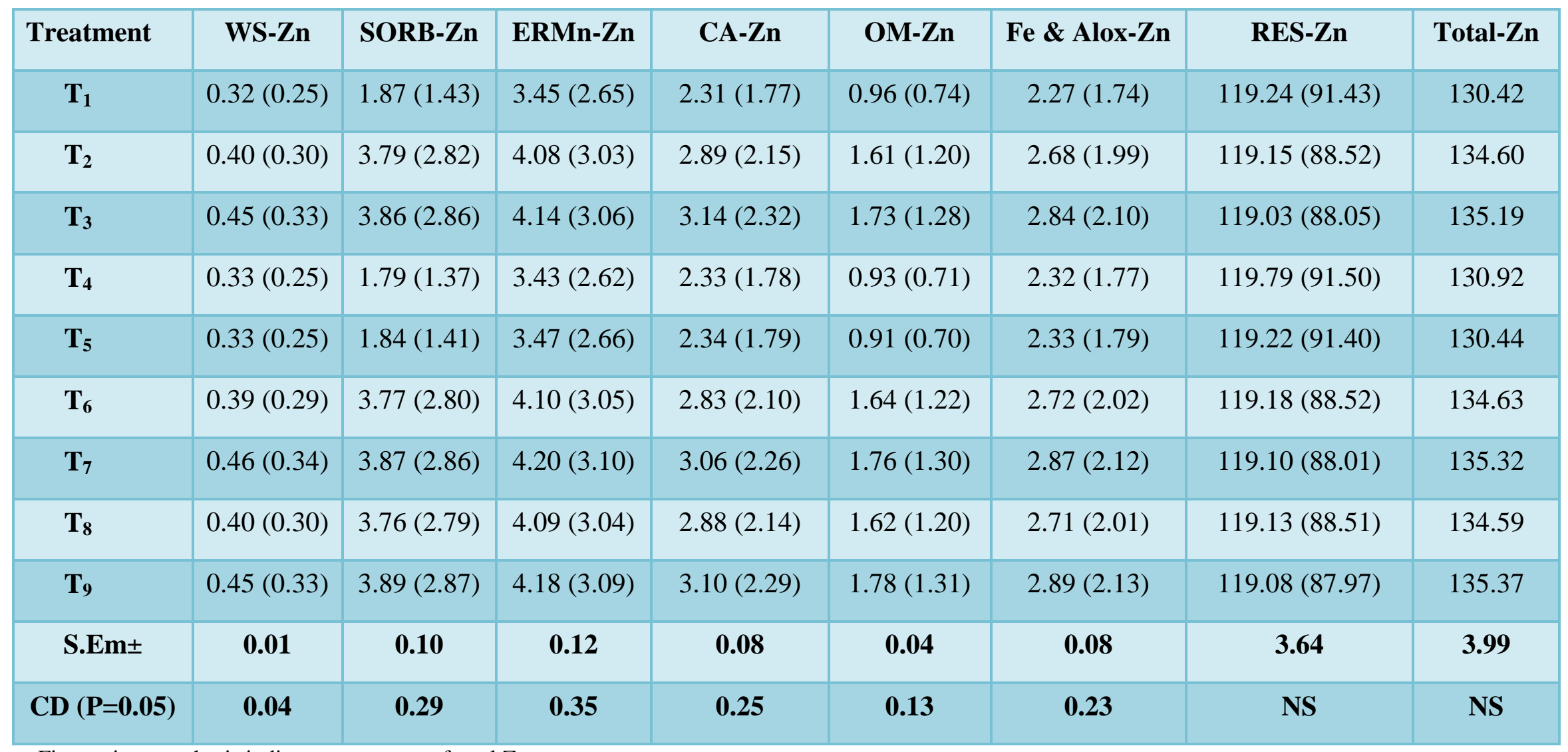

Figures in parenthesis indicate percentage of total $\mathrm{Zn}$ 
Fig.1 Distribution of zinc fractions (WS-Zn, SORB-Zn, CA-Zn, OM-Zn, Fe \& Alox-Zn) (mg $\mathrm{kg}^{-1}$ ) in soil at harvest of greengram as influenced bysoil and foliar application of zin

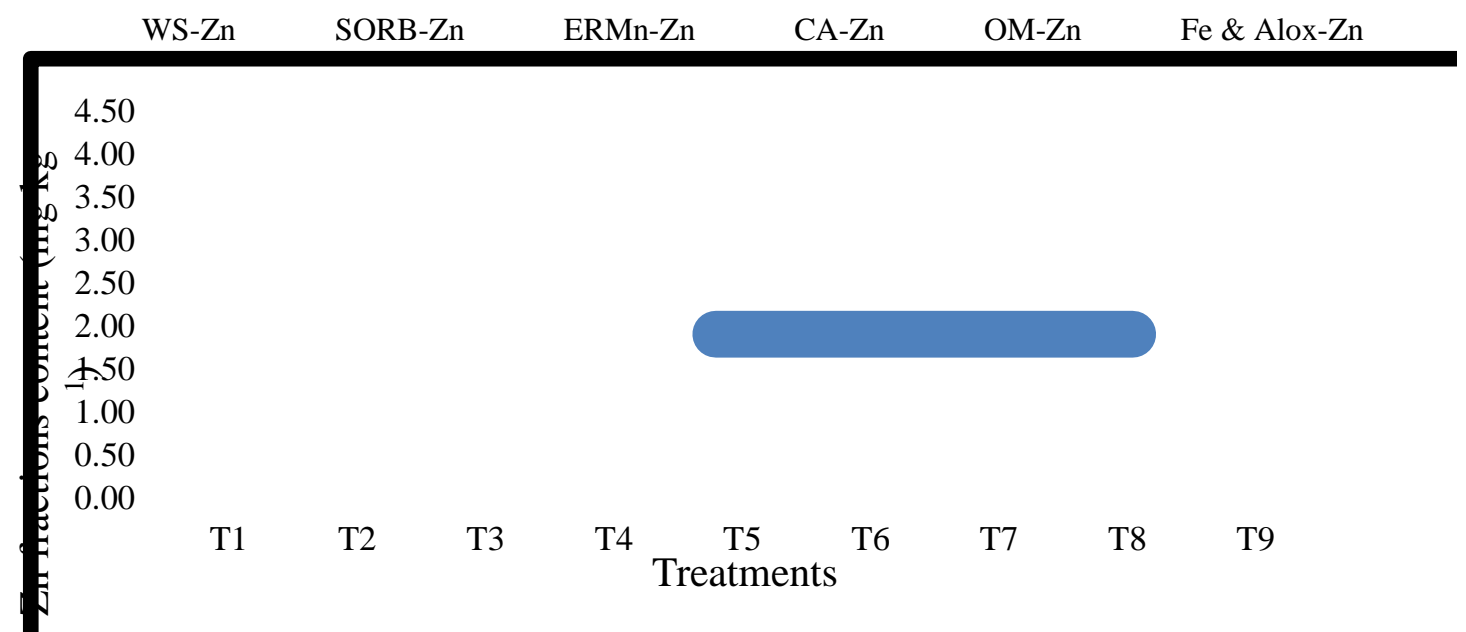

\section{Boron}

Boron content in the soil did not varied significantly due to treatments. However higher $\mathrm{B}$ content of $0.35 \mathrm{mg} \mathrm{kg}^{-1}$ was observed in $\mathrm{T}_{1}(\mathrm{NPK}+\mathrm{FYM})$ and the minimum boron content was recorded in $\mathrm{T}_{9}$ $\left(0.31 \mathrm{mg} \mathrm{kg}^{-1}\right)$ which received $\mathrm{T}_{3}+\mathrm{FS}$ of $\mathrm{Zn}$ EDTA @ $1.00 \%$.Total zinc content in soil not differed significantly due to treatment. However, higher total zinc was observed in treatment $\mathrm{T}_{9}\left(135.37 \mathrm{mg} \mathrm{kg}^{-1}\right)$ which received $\mathrm{T}_{3}+\mathrm{FS}$ of $\mathrm{Zn} \mathrm{EDTA} \mathrm{@} 1.00$ per cent followed by treatment $\mathrm{T}_{7}\left(135.32 \mathrm{mg} \mathrm{kg}^{-1}\right)$ and lowest total zinc was observed in the treatment $\mathrm{T}_{1}(\mathrm{NPK}+\mathrm{FYM})$ which was 130.42 $\mathrm{mg} \mathrm{kg}^{-1}$.

Distribution of zinc fractions in soil at harvest of greengram

\section{Sorbed water soluble zinc}

Significantly higher water soluble fraction was observed in treatment $\mathrm{T}_{7}\left(\mathrm{~T}_{3}+\mathrm{FS}\right.$ of $\mathrm{Zn}$ EDTA@ $0.5 \%)\left(0.46 \mathrm{mg} \mathrm{kg}^{-1}\right)$ followed by $\mathrm{T}_{9}\left(0.45 \mathrm{mg} \mathrm{kg}^{-1}\right)$ and $\mathrm{T}_{3}\left(0.45 \mathrm{mg} \mathrm{kg}^{-1}\right)$ and were significantly higher than rest of the treatments $\mathrm{T}_{1} \mathrm{NPK}+\mathrm{FYM}\left(0.32 \mathrm{mgkg}^{-1}\right), \mathrm{T}_{2}$ $\left(0.40 \mathrm{mgkg}^{-1}\right), \mathrm{T}_{4}\left(0.33 \mathrm{mgkg}^{-1}\right), \mathrm{T}_{5}(0.33 \mathrm{mg}$ $\left.\mathrm{kg}^{-1}\right), \mathrm{T}_{6}\left(0.39 \mathrm{mg} \mathrm{kg}^{-1}\right)$ and $\mathrm{T}_{8}\left(0.40 \mathrm{mg} \mathrm{kg}^{-1}\right)$.

zinc

Sorbed zinc fraction varied significantly due to treatments and higher sorbed zinc content was recorded in treatment $\mathrm{T}_{9}\left(\mathrm{~T}_{3}+\mathrm{FS}\right.$ of $\mathrm{Zn}$ EDTA @ $1.00 \%$ ) which was $3.89 \mathrm{mg} \mathrm{kg}^{-}$ ${ }^{1}$ which was significantly higher than treatments $\mathrm{T}_{1}$ i.eNPK + FYM $\left(1.87 \mathrm{mg} \mathrm{kg}^{-1}\right)$, $\mathrm{T}_{4}\left(1.79 \mathrm{mg} \mathrm{kg}^{-1}\right)$ and $\mathrm{T}_{5}\left(1.84 \mathrm{mg} \mathrm{kg}^{-1}\right)$ and on par with rest of the treatments $\left(\mathrm{T}_{2}, \mathrm{~T}_{3}, \mathrm{~T}_{6}\right.$, $\left.\mathrm{T}_{7}, \mathrm{~T}_{8}\right)$.

\section{Easily reducible manganese bound zinc}

The reducible manganese bound zinc content in soil differed significantly due to treatment. Significantly higher easily reducible manganese bound fraction was observed in treatment $\mathrm{T}_{7}\left(4.2 \mathrm{mg} \mathrm{kg}^{-1}\right)$ which received $\mathrm{T}_{3}+$ FS of Zn EDTA @ 0.50 per cent followed by $\mathrm{T}_{9}$ (4.18 mg kg $\mathrm{mg}^{-1}$ ) and were on par with treatment $\mathrm{T}_{2}\left(4.08 \mathrm{mg} \mathrm{kg}^{-1}\right), \mathrm{T}_{3}\left(4.14 \mathrm{mg} \mathrm{kg}^{-1}\right), \mathrm{T}_{6}$ (4.10 mg kg-1) and $\mathrm{T}_{8}\left(4.09 \mathrm{mg} \mathrm{kg}{ }^{-1}\right)$ and significantly higher than treatment $\mathrm{T}_{1}$ i.e NPK + FYM (3.45 mg kg-1), $\mathrm{T}_{4}\left(3.43 \mathrm{mg} \mathrm{kg}^{-1}\right)$ and $\mathrm{T}_{5}$ $\left(3.47 \mathrm{mg} \mathrm{kg}^{-1}\right)$. 


\section{Carbonate bound zinc}

Carbonate bound fraction varied significantly due to treatments and higher Carbonate boundzinc content was recorded in treatment $\mathrm{T}_{3}\left(\mathrm{~T}_{1}+\mathrm{SA}\right.$ of $\left.\mathrm{ZnSO}_{4} .7 \mathrm{H}_{2} \mathrm{O} @ 10 \mathrm{~kg} \mathrm{ha}^{-1}\right)$ which was $3.14 \mathrm{mg} \mathrm{kg}^{-1}$ which was significantly higher than treatments $\mathrm{T}_{1}$ i.eNPK + FYM $(2.31 \mathrm{mg} \mathrm{kg}$ $\left.{ }^{1}\right), \mathrm{T}_{4}\left(2.33 \mathrm{mg} \mathrm{kg}^{-1}\right), \mathrm{T}_{5}\left(2.34 \mathrm{mg} \mathrm{kg}^{-1}\right)$ and $\mathrm{T}_{6}$ $\left(2.83 \mathrm{mg} \mathrm{kg}^{-1}\right)$, and on par with rest of the treatments $\quad \mathrm{T}_{2} \quad(2.89 \quad \mathrm{mg}$ $\left.\mathrm{kg}^{-1}\right), \mathrm{T}_{7}\left(3.06 \mathrm{mg} \mathrm{kg}^{-1}\right), \mathrm{T}_{9}\left(3.10 \mathrm{mg} \mathrm{kg}^{-1}\right)$ and $\mathrm{T}_{8}\left(2.88 \mathrm{mg} \mathrm{kg}^{-1}\right)$.

\section{Organic bound zinc}

The organic bound zinc content in soil differed significantly due to treatment. Significantly higher Organic bound fraction was observed in treatment $\mathrm{T}_{9}\left(\mathrm{~T}_{3}+\mathrm{FS}\right.$ of Zn EDTA @ 1.00 $\%)\left(1.78 \mathrm{mg} \mathrm{kg}^{-1}\right)$ and was on par with treatment $\mathrm{T}_{7}\left(1.76 \mathrm{mg} \mathrm{kg}^{-1}\right), \mathrm{T}_{3}\left(1.73 \mathrm{mg} \mathrm{kg}{ }^{-1}\right)$ and significantly higher than $\mathrm{T}_{6}\left(1.64 \mathrm{mg} \mathrm{kg}^{-1}\right)$ and $\mathrm{T}_{8}\left(1.62 \mathrm{mg} \mathrm{kg}^{-1}\right), \mathrm{T}_{2}\left(1.61 \mathrm{mg} \mathrm{kg}^{-1}\right), \mathrm{T}_{1}$ i.e NPK + FYM $\left(0.96 \mathrm{mg} \mathrm{kg}^{-1}\right), \mathrm{T}_{4}\left(0.93 \mathrm{mg} \mathrm{kg}^{-1}\right)$ and $\mathrm{T}_{5}\left(0.91 \mathrm{mg} \mathrm{kg}^{-1}\right)$.

\section{Fe \& Al oxides bound zinc}

$\mathrm{Fe} \& \mathrm{Al}$ oxides bound fraction varied significantly due to treatments and higher Fe \& Al oxides bound zinc content was recorded in treatment $\mathrm{T}_{9}\left(\mathrm{~T}_{3}+\mathrm{FS}\right.$ of Zn EDTA @ 1.00 \%)which was $2.89 \mathrm{mg} \mathrm{kg}{ }^{-1}$ which was significantly higher than treatments $\mathrm{T}_{1}$ i.eNPK + FYM $\left(2.27 \mathrm{mg} \mathrm{kg}^{-1}\right), \mathrm{T}_{4}\left(2.32 \mathrm{mg} \mathrm{kg}^{-1}\right)$ and $\mathrm{T}_{5}$ (2.33 mg kg-1) and on par with rest of the treatments $\mathrm{T}_{7}\left(2.87 \mathrm{mg} \mathrm{kg}^{-1}\right), \mathrm{T}_{3}\left(2.84 \mathrm{mg} \mathrm{kg}^{-1}\right)$, $\mathrm{T}_{6}\left(2.72 \mathrm{mg} \mathrm{kg}^{-1}\right), \mathrm{T}_{2}\left(2.68 \mathrm{mg} \mathrm{kg}^{-1}\right)$ and $\mathrm{T}_{8}(2.71$ $\left.\mathrm{mg} \mathrm{kg}^{-1}\right)$.

\section{Residual zinc}

The residual zinc content in soil not differed significantly due to treatment. However, higher residual zincwas observed in treatment $\mathrm{T}_{4}$ $\left(119.79 \mathrm{mg} \mathrm{kg}^{-1}\right)$ which received $\mathrm{T}_{1}+\mathrm{FS}$ of $\mathrm{Zn}$ EDTA@0.5 per cent and lowest residual zinc was observed in the treatment $\mathrm{T}_{3}\left(\mathrm{~T}_{1}+\mathrm{SA}\right.$ of $\mathrm{ZnSO}_{4} .7 \mathrm{H}_{2} \mathrm{O} @ 10 \mathrm{~kg} \mathrm{ha}^{-1}$ ) which was 119.03 $\mathrm{mg} \mathrm{kg}^{-1}$.

\section{Total zinc}

Higher total zinc was observed in treatment $\mathrm{T}_{9}$ $\left(135.37 \mathrm{mg} \mathrm{kg}^{-1}\right)$ which received $\mathrm{T}_{3}+\mathrm{FS}$ of $\mathrm{Zn}$ EDTA@1.00 per cent followed by treatment $\mathrm{T}_{7}\left(135.32 \mathrm{mg} \mathrm{kg}^{-1}\right)$ and lowest total zinc was observed in the treatment $\mathrm{T}_{1}(\mathrm{NPK}+\mathrm{FYM})$ which was $130.42 \mathrm{mg} \mathrm{kg}^{-1}$. The changes in $\mathrm{Zn}$ fractions were dependent on number of mechanisms involving: surface complexation of the residual zinc form by organic ligands released from roots, the inhibition of iron $(\mathrm{Fe})$ and aluminum $(\mathrm{Al})$ crystallization providing reactive surfaces and effective sinks for zinc, thus enhancing further dissolution of residual zinc and by the adsorption of organic ligands to the oxide surfaces. Ligand adsorption usually conveys negative charge on to the oxide surfaces and thus increases zinc adsorption by oxides (Barrow 1987).

Application of zinc increased all the zinc fractions in soil except residual fraction and total zinc which showed non-significant difference. Zinc application increased the sorbed fraction to the greater extent, whereas with respect to other fractions mere increase in the content over NPK + FYM was observed. An increase in the concentration of zinc in all the fractions except residual zinc (RES) due to the applied zinc sulphate, which has high solubility and mobility in soil got distributed into soluble and sparingly soluble fractions of zinc such as water soluble (WS), sorbed (SORB), easily reducible manganese bound zinc (ERMn) calcium bound (CA) and organic bound zinc $(\mathrm{OM})$, iron and aluminum oxides bound zinc (Fe \& Al-ox). This indicates that applied zinc in the form of zinc sulphate in sandy loam soil mainly concentrated in easily and sparingly soluble fractions but not in the residual fraction and thereby an increase in its availability in soil was observed due to their contribution to the available pool (Patil and Kedlaya, (1988). 


\section{References}

Akay, A., 2011, Effect of zinc fertilizer applications on yield and element contents of some registered chickpeas varieties. Afr. J. Biotechnol., 10(61): 13090-13096.

Ali, H., 2004, Interactive effects of seed inoculation and phosphorous application on growth and yield of chick pea (Cicer arietinum L.). Int. J. Agric. Biol., 6(1):110-112.

Anonymous, 2016-17a. Annual report. Ministry of agriculture and farmers welfare, Director of pulse development, Government of India, Pp 9.

Anonymous, 2017b. Greengram, Indian pulse and grain association, Mumbai.

Barrow, N. J., 1987, The effects of phosphate on zinc sorption by a soil. J. Soil Sci., 38: 453-459.

Gomez, K. A. and Gomez, A. A., 1984, Statistical procedures for agricultural research. $2^{\text {nd }}$ Ed. John Wiley Sons, New York.

Jackson, M. L., 1973, Soil Chemical Analysis. Prentice Hall of India Pvt. Ltd., New Delhi. Pp.134-204.

Krishna, S., 1995, Effect of sulphur and zinc application on yield, sulphur and zinc uptake and protein content of mungbean (green gram). Legume Res., 18 (2): 8992.

Kulandaivel, S., Mishra, B. N., Gangiah, B. and Mishra, P. K.,2004, Effect of levels of zinc and iron and their chelation on yield and soil micronutrient status in hybrid rice (Oryza sativa)- wheat (Triticum aestivum) cropping system.Indian $J$. Agron.,49(2): 80-83.

Lindsay, W. L. and Norvell, W. A., 1978, Development of DTPA soil test for ascertaining available iron, copper, manganese and zinc. Soil Sci. Soc. Am. J., 42: 421-428.

Lindsay, W. L.,1979, Chemical equilibria in soils. Johnwiley and Sons. New York, USA.

Ma, Y. B. and Uren, N. C., 1995, Application of a new fractionation scheme for heavy metals in soils. Commun. Soil Sci. Pl. Anal., 26(19-20): 3291-3303.

Page, A. L., Miller, R. H. and Keeney, D. R., 1982, Methods of soil analysis. Part 2chemical and microbiological properties. $2^{\text {nd }}$ edition. Agronomy No. 9 Part 2. ASA, SSSA, Madison, Wisconsin, USA.

Patil, C. and Kedlaya, N., 1988, Soil zinc fractions and their availability in Oxisol. J. Indian Soc. Soil Sci., 36: 487-491.

Piper, C. S., 1966, Soil and Plant Analysis, Inter-science Publishers, Inc., New York. pp. 368.

Sharma, S.K., Kapoor, S. and Rana, S.S., 2016,effect of the application of nitrogen, zincand boron on soil properties and available nutrients status after the harvest of wheat. Int. J.Adv. Agric.Sci.Tech., 3(7): 12-20.

Srivastava, R. P. and Ali, M., 2004. Nutritional Quality of Pulses, IIPR, Kanpur, P-22.

\section{How to cite this article:}

Vinodkumar, H. V., S. Channakeshava, B. Basavaraja and Ananathakumar. 2020. Effect of Soil and Foliar Application of Zinc on Growth and Yield of Greengram (Vigna radiate L.). Int.J.Curr.Microbiol.App.Sci. 9(04): 501-512. doi: https://doi.org/10.20546/ijcmas.2020.904.060 